\title{
Equilibrium and Kinetic Study of Ammonium Sorption by Raphia farinifera
}

\author{
Pawel Staroń $(\mathbb{D} \cdot$ Paulina Sorys • \\ Jarosław Chwastowski
}

Received: 17 May 2019 / Accepted: 25 September 2019 / Published online: 24 October 2019

(C) The Author(s) 2019

\begin{abstract}
The study investigated the sorption capacity of biosorbent-raphia sp. against ammonia. Raphia fibers were used without and with the modification of its surface with $\mathrm{NaCl}, \mathrm{NaNO}_{3}$, and $\mathrm{K}_{2} \mathrm{SO}_{4}$. The data was analyzed in the state of equilibrium using four isotherm models such as Langmuir, Freudlich, Temkin, and Dubinin-Radushkevich. The equilibrium of ammonia sorption for all studied systems was best described by the Freudlich isotherm model. On its basis, it can be assumed that the studied process is of chemical nature, which results from the value of the coefficient $1 / n<1$. In order to confirm the sorption mechanism, analysis of the kinetics of the ammonia sorption process on raphia fibers was performed. Four kinetic models of sorption were calculated: pseudo-first-order model, pseudosecond-order model, Elovich model, and WebberMorris intermolecular diffusion model. The sorption kinetics of the modeled ammonia waste were carried out using unmodified palm fibers and all kinds of surface modification. This process was best described by the pseudo-second-order sorption model, which can be considered as a confirmation of the chemical nature of ammonia sorption on raphia sp. fibers.
\end{abstract}

Keywords Ammonium $\cdot$ Biosobent $\cdot$ Raphia $\cdot$ Sorption · Palm

P. Staroń $(\bowtie) \cdot$ P. Sorys $\cdot$ J. Chwastowski

Department of Engineering and Chemical Technology, Cracow University of Technology, 24 Warszawska St, 31-155 Cracow, Poland

e-mail: pstaron@chemia.pk.edu.pl

\section{Introduction}

Ammonia is part of the natural cycle of nitrogen circulation in nature; however, an artificial source of ammonia in the case of water pollution causes excessive eutrophication and algal bloom, which leads to disturbance of the balance of the aquatic ecosystem. Increased ammonia concentration in water has a particularly negative effect on fish development causing gill damage, hyperplasia, and significant reduction of growth rate (Cui et al. 2016; Conley et al. 2009; Długosz and Banach 2018b).

Ammonia occurs naturally in the environment mainly in the form of ammonium salts. It is released in the volatile $\mathrm{NH}_{3}$ form mainly due to decomposition of nitrogen-containing organic substances and as a result of volcanic activity. Another natural source of ammonia is electrical discharges that arise in the atmosphere that allow the reaction of oxygen with molecular nitrogen. As a result of the reaction, ammonia and its oxidation products are formed, which subsequently react with each other to form ammonium nitrate (V) and ammonium nitrate (III). Part of the nitrates produced according to this mechanism reaches the earth's surface, from which they are absorbed by plants, because they contain nitrogen in a form that is available to them (Appl 1999). Ammonia is widely used in the production of fertilizers and animal feed as well as in the production of fibers, plastics, explosives, paper, and rubber (Šiljeg et al. 2010). The largest uncontrolled emission of ammonia to the environment comes from livestock 
Table 1 Modification of the surface of raphia fibers

\begin{tabular}{llll}
\hline $\begin{array}{l}\text { L.p. } \\
\text { agent }\end{array}$ & $\begin{array}{l}\text { Modification } \\
{\left[\mathrm{mol} / \mathrm{dm}^{3}\right]}\end{array}$ & $\begin{array}{l}\text { Modification } \\
\text { time }[\mathrm{h}]\end{array}$ \\
\hline 1 & $\mathrm{NaCl}$ & 1 & 3 \\
2 & & & 54 \\
3 & $\mathrm{NaNO}_{3}$ & 1 & 16 \\
4 & $\mathrm{~K}_{2} \mathrm{SO}_{4}$ & 0.5 & 16 \\
\hline
\end{tabular}

breeding, manure management, and fertilizer application. In case of insufficient ventilation of the breeding rooms, respiratory diseases appear in the animals, which results in a decrease in the production of milk, meat, and eggs (Alberdi et al. 2016; Henry and Aherne 2014). Currently used techniques of removing ammonia from water and wastewater are biological method using activated sludge to remove nitrogen compounds in sewage treatment plants, division in the air stream, and ion exchange carried out in columns with zeolite filling, chemical precipitation, ion exchange, membrane separation (Zhang et al. 2009; Jorgensen and Weatherley 2003; Shalini and Joseph 2012; Huang et al. 2015).

An alternative to commonly used techniques is sorption of ammonia on a properly selected sorbent. The sorbent should meet a number of requirements: be easily accessible and durable both mechanically and chemically, have high sorption capacity and high affinity for analyte, and enable recycling by lowering process costs (Veliscek-Carolan et al. 2019; Azimi et al. 2019; Bhardwaj and Bhaskarwar 2018; Hu et al. 2019).

The aim of the research was to check the possibility of using raphia fibers to remove ammonia from aqueous solutions. Raphia fibers belong to organic materials containing lignin and cellulose in their composition ( $\mathrm{Xu}$ et al. 2018). The ammonia removal process was carried out in the batch system, allowing to obtain information about the maximum sorption capacity of the material in relation to the analyzed analyte. Raphia fibers have also been subjected to chemical modification to improve its sorption capacity. Obtained results of the research allowed for adaptation of the sorption isotherm and determination of sorption kinetics allowing to obtain basic information on the mechanisms of ammonia sorption on raphia fibers. The solute removal rate controlling residence time in the liquid-solid interface is expressed by the sorption kinetics. One of the most important factors in the designing of the sorption system is the sorption rate, because the kinetics determine the reactor dimensions what is connected with the solute residence time. In order to understand the sorption kinetics, various models have been studied.

Pseudo-first-order and pseudo-second-order kinetic models are the most used to study metal sorption kinetics to solids (Veneu et al. 2018; Guo and Wang 2019).

\section{Materials and Methods}

\subsection{Materials}

The research involved the use of raphia fiber (Raphia farinifera) purchased in the commercial store. Raphia test was prepared by cutting fibers into pieces with the length of approx. 3-4 $\mathrm{mm}$ and a five-fold rinsing in demineralized water. One rinse cycle lasted 10 $15 \mathrm{~min}$. The aim of the washing was to purify and unify the research material. The most favorable purification conditions were obtained by mixing approx. $20 \mathrm{~g}$ of raphia in approx. $1.5 \mathrm{dm}^{3}$ of demineralized water. All used solutions were prepared in distilled water. Reagents used in the tests were purchased from Sigma-Aldrich and were characterized by analytical purity.

\subsection{Surface Modification}

The process of surface modification of the raphia fibers was carried out using aqueous salt solutions according to Table 1. Substitution of silicon by aluminum atoms in the crystal backbone leads to an additional negative charge balanced by surrounding counterions (such as $\mathrm{Na}+\mathrm{K}+, \mathrm{Ca} 2+$, and $\mathrm{Mg} 2+$ ), and these counterions are easily exchanged by other surrounding cations in contact solution. To $10 \mathrm{~g}$ of raphia, $100 \mathrm{~cm}^{3}$ of the modifying solution was added and mixed for a limited time.

According to the fundamental of ion exchange between solid and liquid phases, the ion exchange process between zeolite frame and aqueous ammonium solution can be expressed by the following equation.

$\mathrm{Rf}-\mathrm{Me}^{\mathrm{n}+}+\mathrm{nNH}_{4}{ }^{+}=\mathrm{Rf}-\mathrm{nNH}_{4}{ }^{+}+\mathrm{Me}^{\mathrm{n}+}$ 
Table 2 Isotherm model equations

\begin{tabular}{|c|c|c|c|}
\hline No. & & Equation & Reference \\
\hline \multicolumn{4}{|c|}{ Isotherm models } \\
\hline 1 & Langmuir & $\frac{C_{e}}{q_{e}}=\frac{C_{e}}{q_{\max }}+\frac{1}{b \cdot q_{\max }}$ & (Azizian et al. 2018) \\
\hline 2 & Freundlich & $\log q_{e}=\log K_{f}+\frac{1}{n} \log C_{e}$ & (Coles and Yong 2002) \\
\hline 3 & Temkin & $\begin{array}{l}q_{e}=B \ln K_{t}+B \ln C_{e} \\
B=\frac{R T}{b_{t}}\end{array}$ & (Araújo et al. 2018) \\
\hline 4 & Dubinin-Radushkevich & $\begin{array}{l}\ln q_{e}=\ln q_{d}-\left(B_{d} \varepsilon^{2}\right) \\
\varepsilon=R \operatorname{Tln}\left(1+\frac{1}{C_{e}}\right)\end{array}$ & (Abdelnaeim et al. 2016) \\
\hline
\end{tabular}

where Ze and M represent the zeolite and the loosely held cations in zeolite, respectively, and $n$ is the number of electric charge (Lin et al. 2013).

\subsection{Sorption Process}

The ammonia sorption process was carried out in a batch dynamic mixing system. The variable parameters of the sorption process were the concentration of ammonia and the time of running the process. The sorption process was carried out in a $60-\mathrm{cm}^{3} \mathrm{PP}$ beaker; $0.5 \mathrm{~g}$ of previously prepared raphia fibers and $40 \mathrm{~cm}^{3}$ of ammonia solution were used each time. Five concentrations of model solutions were determined for which further tests were conducted: $1,3,5,7$, and $9 \mathrm{mmol} / \mathrm{dm}^{3}$. The sorption time was $0.5,1,2,4,6,10$, and $15 \mathrm{~min}$. After the sorption process, the solutions were filtered, and then, the ammonia content was determined by titration.

\subsection{Physicochemical Characteristics}

The analysis of the elemental composition of $r a$ phia fibers before and after the sorption process was carried out using the compact energydispersive spectrometer X-ray PW4025/00 MiniPal by PANalytical B.V. A specific surface area test was carried out using a ASAP 2010 deaerator station. Before measurement, samples were dried in a helium atmosphere at $110{ }^{\circ} \mathrm{C}$ for $8 \mathrm{~h}$, then under vacuum at $100{ }^{\circ} \mathrm{C}$ and 0.001 Tor for $8 \mathrm{~h}$. Surface analysis was performed with an LEO 1430 VP scanning electron microscope. SEM photomicrographs were taken on Hitachi TM-3000 equipped with an X-ray micro analyzer EDS. CHN analysis was performed using the Perkin Elmer Type $2400 \mathrm{CHN}$ analyzer. Fourier transform infrared spectroscopy was performed on a Scimitar Series FTS 2000 from Digilab.

Table 3 Kinetic model equations

\begin{tabular}{llll}
\hline No. & Equation & Reference \\
\hline 1 & Pseudo-first order & $\log \left(q_{e}-q_{t}\right)=\log _{q e}-\frac{k_{l}}{2.303} t$ & (Długosz and Banach 2018a) \\
2 & Pseudo-second order & $\frac{t}{q_{t}}=\frac{1}{k_{2} q_{e}^{2}}+\frac{t}{q_{e}}$ & (Simonin 2016) \\
& & $q_{t}=k_{i d} t^{0.5}+I$ & (Zhu et al. 2016) \\
4 & Weber-Morris & $q_{t}=\frac{1}{\beta} \ln (\alpha \beta)+\frac{1}{\beta} \ln (t)$ & (Inyang et al. 2016) \\
\hline
\end{tabular}




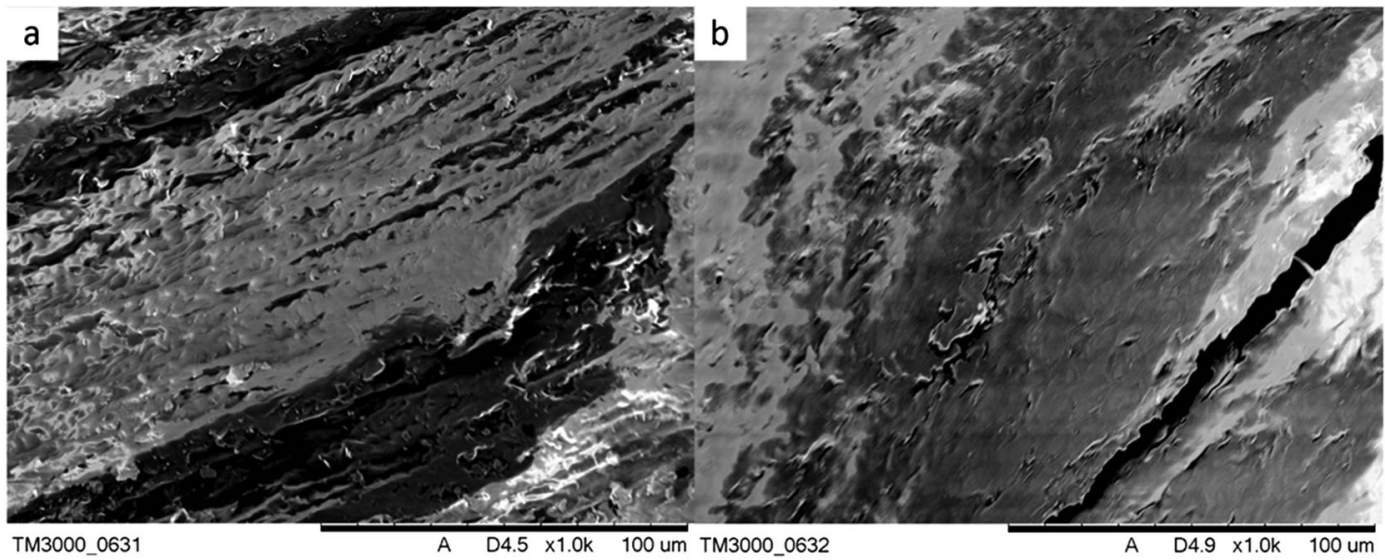

Fig. 1 SEM micrograph of raphia fiber: a before sorption, $\mathbf{b}$ after sorption

\subsection{Equilibrium Studies}

The equilibrium parameters of ammonia sorption on raphia fibers were modeled on the basis of the isotherms: Langmuir, Freundlich, Temkin, and DubininRadushkevich isotherms (Table 2).

\subsection{Kinetic Models}

Investigating the influence of the sorption time allows to determine the mechanisms of the sorption process. In order to determine the effect of contact time of raphia fibers (before and after modification), sorption capacity of raphia fiber in relation to ammonia at different times at various initial concentrations was investigated. Table 3 presents the kinetic models used.

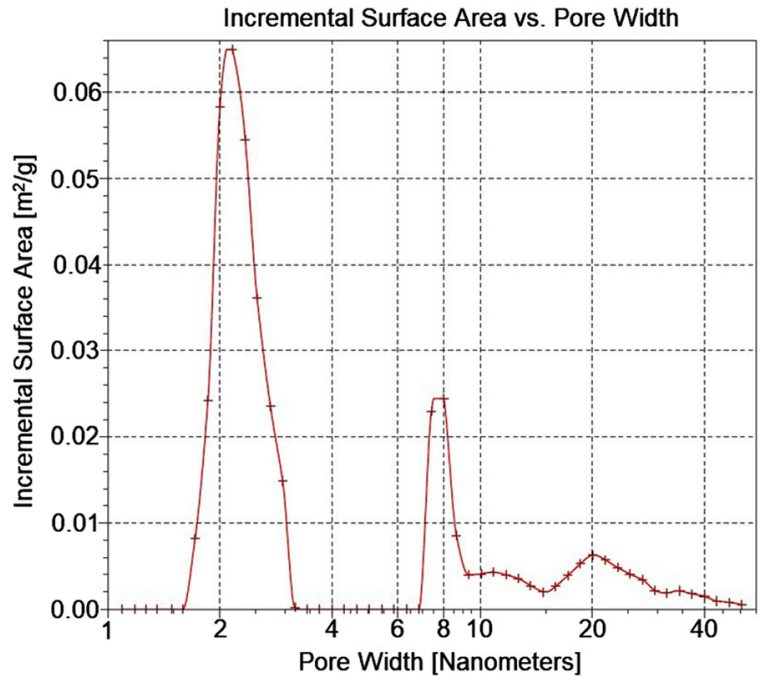

Fig. 2 Porosity graph of coconut fiber

\section{Result and Discussion}

\subsection{Materials Characterization}

The raphia fibers prior to the sorption process have a heterogeneous structure with a fibrous structure (Fig. 1a), whereas the structure of raphia fibers after the sorption process (unmodified-UM) was characterized by a structure with greater homogeneity (Fig. 1b). BET analysis showed that the specific surface area of raphia fibers had a specific surface area of $1.079 \mathrm{~m}^{2} / \mathrm{g}$; moreover, the fiber surface is characterized by a mesoporous structure (Fig. 2).

Analysis of the XRF spectrum of raphia without surface modification and after its modification showed the presence of nine elements. The material was marked

Table 4 Elemental composition of raphia without modification and modification

\begin{tabular}{lllll}
\hline \multirow{2}{*}{ Element } & \multicolumn{2}{l}{ Content [\%] } & & \\
\cline { 2 - 5 } & Without modification & $\mathrm{NaNO}_{3}$ & $\mathrm{~K}_{2} \mathrm{SO}_{4}$ & $\mathrm{NaCl} 54 \mathrm{~h}$ \\
\hline $\mathrm{Si}$ & 17 & 26 & 15 & 5 \\
$\mathrm{P}$ & 15 & 27 & 10 & 18 \\
$\mathrm{~S}$ & 6 & 15 & 5 & 6 \\
$\mathrm{~K}$ & 10 & - & 52 & - \\
$\mathrm{Ca}$ & 44 & 24 & 15 & 60 \\
$\mathrm{Ti}$ & 1 & - & - & - \\
$\mathrm{Mn}$ & 2 & 1 & 1 & 6 \\
$\mathrm{Fe}$ & 4 & 6 & 3 & 5 \\
$\mathrm{Ni}$ & 1 & 1 & - & 1 \\
$\mathrm{Al}$ & 3 & 1 & - & 1 \\
\hline
\end{tabular}




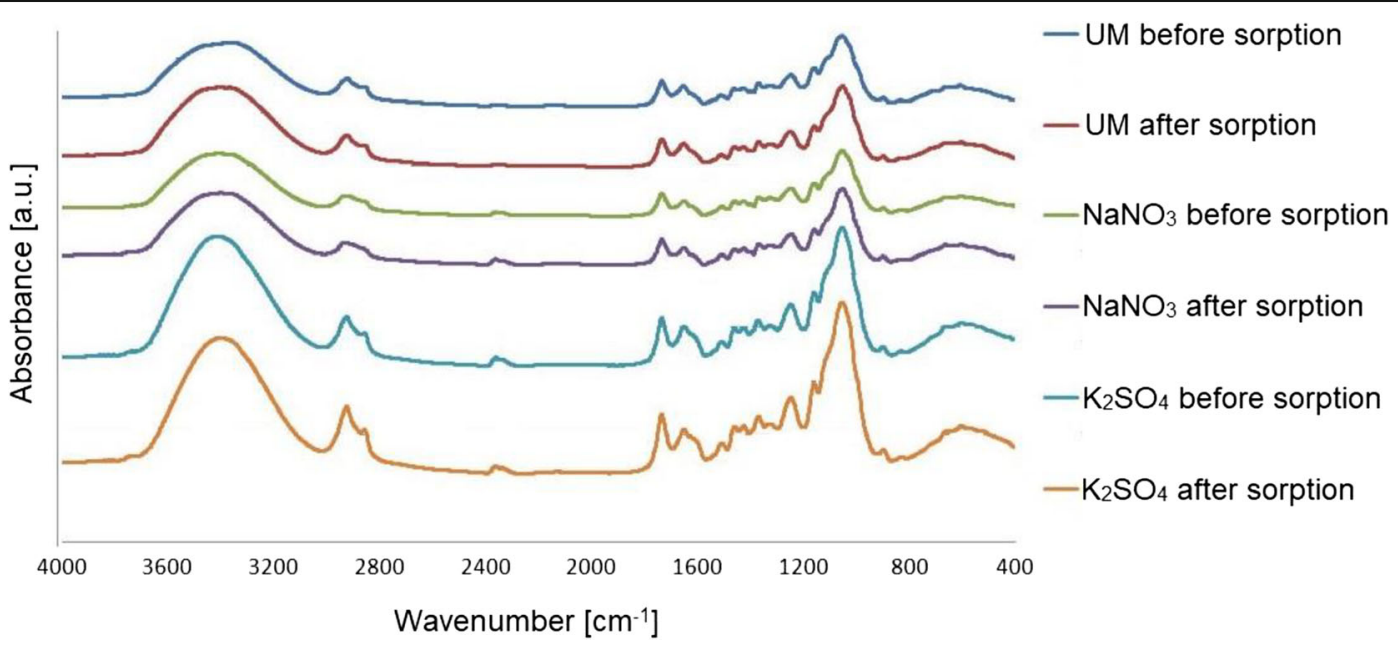

Fig. 3 Raphia IR interferogram

with the highest content of calcium, silicon, phosphorus, and potassium. In addition, based on elemental analysis of $\mathrm{CHN}$, it was found that the content was equal to $\mathrm{C}$ : 46.04\%, H: $6.18 \%$, and N: $0.77 \%$. These values are similar to those obtained by other researchers during analyses of organic materials (Bispo et al. 2018; Chwastowski et al. 2017).

The results of the semi-quantitative (nonpatterned) analysis are shown in Table 4. The XRF technique allows the determination of elements heavier than sodium $(\mathrm{MNa}=22.99 \mathrm{~g} / \mathrm{mol})$. Raphia as an organic substance consists mainly of carbon $(\mathrm{MC}=12.01 \mathrm{~g} / \mathrm{mol})$, which is why the presented percentage composition of elements present in the structure of raphia is inflated and is illustrative (Hunt and Speakman 2015).

Raphia without surface modification from the elements detected by the XRF technique contains the most calcium (44\%). Silicon, phosphorus, and potassium are present in a smaller amount with a percentage of 17,15 , and $10 \%$, respectively. The analysis showed the presence of sulfur, titanium, manganese, iron, and nickel.

$\mathrm{NaNO}_{3}$ modification caused a decrease in the content of calcium by $45 \%$ and potassium by $100 \%$, which resulted in an increase in the percentage of silicon, phosphorus, and sulfur.

Percentages of calcium, silicon, phosphorus, and potassium are similar and amount to $24,26,27$, and $15 \%$, respectively.

Modification of $\mathrm{K}_{2} \mathrm{SO}_{4}$ caused an increase in the potassium content by $420 \%$, resulting in a $66 \%$ decrease in calcium content. The element with the highest percentage share in this sample is potassium- $52 \%$.

The $\mathrm{NaCl}$ modification reduced the silicon content by $71 \%$ and potassium by $100 \%$, resulting in an increase in the percentage of calcium by $36 \%$. The element with the largest percentage share in this sample is calcium$60 \%$.

Figure 3 shows the IR interferogram of the raphia without surface modification and with the modified surface made before and after the sorption process. In the range of $3600-3200 \mathrm{~cm}^{-1}$, there is an area characteristic for the vibration of the hydroxyl group $(-\mathrm{OH})$. The peak at $1050 \mathrm{~cm}^{-1}$ corresponds to the amino group (-NH), peak $1650 \mathrm{~cm}^{-1}$ carbonyl group $(-\mathrm{COOH})$, peak $2900 \mathrm{~cm}^{-1}$ group $-\mathrm{CH}_{2}-$ (Staroń et al. 2017). The peak at $2360 \mathrm{~cm}^{-1}$ is the result of the presence of $\mathrm{CO}_{2}$. With each measurement, the intensity of this peak increases as opening the measuring chamber of the spectrometer to place the sample caused the diffusion of $\mathrm{CO}_{2}$ from the air in the laboratory inside the device. On the presented interferogram, there are no changes in the peaks for the modified raphia compared to the unmodified material, what results from the modifying substances used. Salts change the acidic and basic surface groups, which changes only the FTIR intensity not spectrum. In addition, slight shifts in the spectrum after the sorption process can be observed, which is possible with overlapping of the peaks associated with $\mathrm{NH}_{4}{ }^{+}$groups (Petit et al. 2006).

One of the most important factors affecting the degree of removal of ammonia from the solution is the 

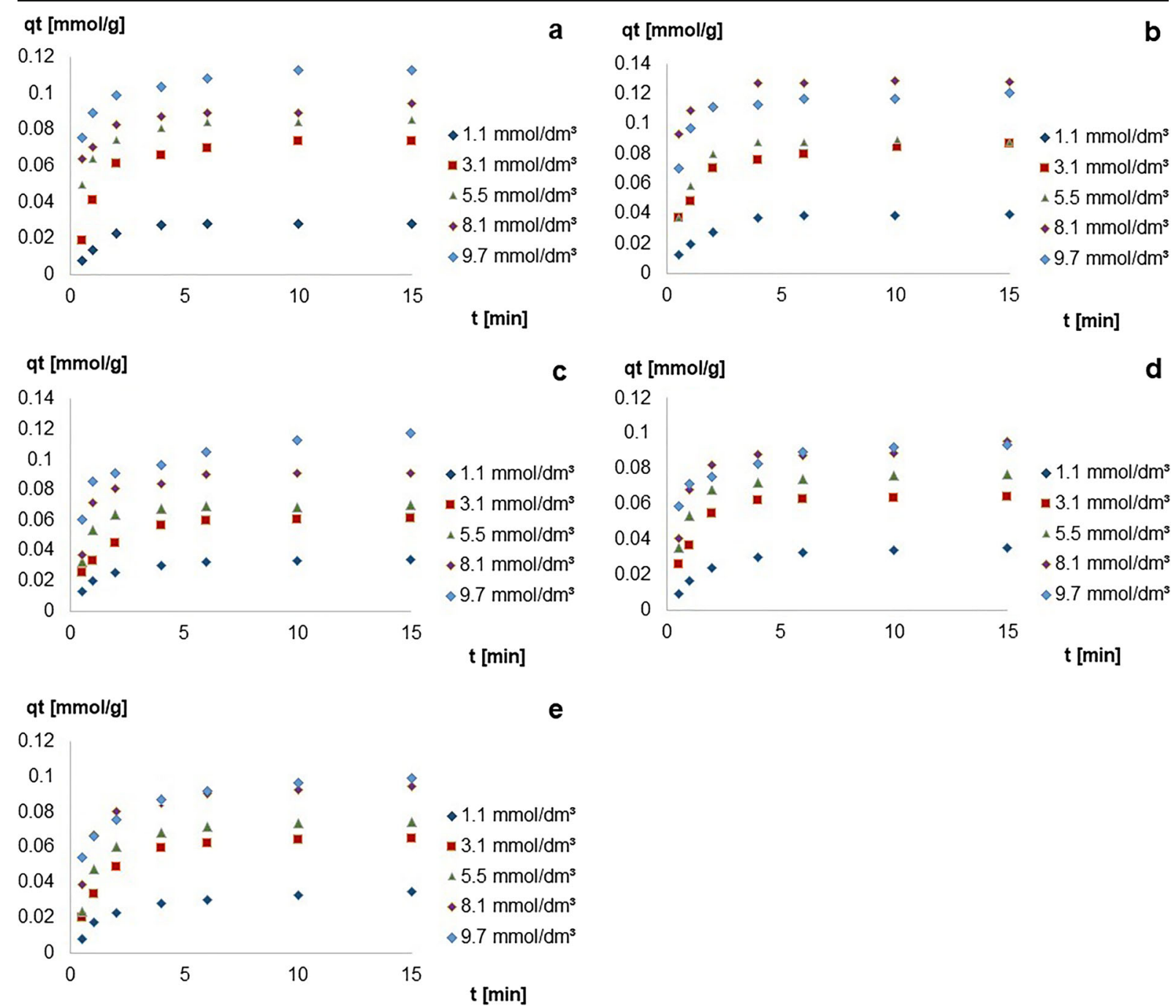

Fig. 4 Sorption of ammonium on raphia fiber over time at different initial concentrations, modification: $\mathbf{a}$ without modification, $\mathbf{b} \mathrm{NaCl} 3 \mathrm{~h}$, c $\mathrm{NaCl} 54 \mathrm{~h}, \mathbf{d ~ N a N O} \mathrm{Na}_{3} 17 \mathrm{~h}, \mathbf{e ~} \mathrm{K}_{2} \mathrm{SO}_{4} 16 \mathrm{~h}$

contact time of the solution with the sorption bed. In Fig. 4, it is observed that with sorption time prolongation, the sorption capacity qt of raphia increases, up to the limit of $0.11 \mathrm{mmol} / \mathrm{g}$ for unmodified material, $0.13 \mathrm{mmol} / \mathrm{g}$ for modified with $\mathrm{NaCl}, 0.10 \mathrm{mmol} / \mathrm{g}$ for $\mathrm{NaNO}_{3}$, and $0.1 \mathrm{mmol} / \mathrm{g}$ for $\mathrm{K}_{2} \mathrm{SO}_{4}$. The highest sorption rate occurs at the beginning of the process until about the second minute. Then, it decreases, until reaching the sixth minute of sorption equilibrium between the content of ammonia in the solution and sorbated by raphia.

Figure 5 shows the degree of removal $\left(R_{\mathrm{e}}\right)$ of ammonia at the equilibrium for individual concentrations of initial ammonia in the model wastewater.
The lower the initial concentration of ammonia, the higher the ammonia removal in equilibrium state $R_{\mathrm{e}}$. The highest removal rate was obtained using raphia modified with $\mathrm{NaCl}$ for $3 \mathrm{~h}$. Increase of sorption with unmodified raphia surface by $\mathrm{NaCl}$ modification for $3 \mathrm{~h}$ occurs only at initial ammonia concentrations below $3 \mathrm{mmol} / \mathrm{dm}^{3}$. The lower the initial concentration of ammonia, the higher the ammonia removal in equilibrium state $R_{\mathrm{e}}$. The highest removal rate was obtained using raphia modified with $\mathrm{NaCl}$ for $3 \mathrm{~h}$. Increase in sorption with modified raphia by $\mathrm{NaCl}$ for $3 \mathrm{~h}$ occurs only at initial ammonia concentrations below $3 \mathrm{mmol} / \mathrm{dm}^{3}$. The modification of raphia surface with $\mathrm{NaCl}$ for $54 \mathrm{~h}, \mathrm{NaNO}_{3}$, and 
Fig. 5 The degree of removal $\left(R_{\mathrm{e}}\right)$ of ammonia on the surface of raphia

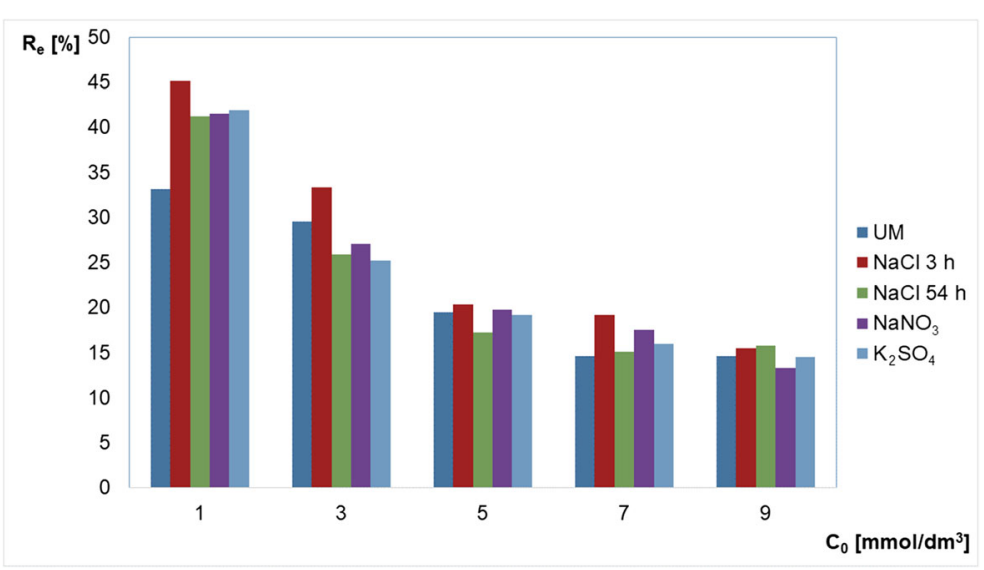

$\mathrm{K}_{2} \mathrm{SO}_{4}$ increases the sorption of ammonia only for a solution $1 \mathrm{mmol} / \mathrm{dm}^{3}$. In other cases, modification of the sorbent surface did not improve the sorption capacity of raphia in relation to ammonia. The modification of raphia surface with $\mathrm{NaCl}$ for $54 \mathrm{~h}$,
$\mathrm{NaNO}_{3}$, and $\mathrm{K}_{2} \mathrm{SO}_{4}$ increases the sorption of ammonia only for a solution of $1 \mathrm{mmol} / \mathrm{dm}^{3}$. In other cases, modification of the sorbent surface did not improve the sorption capacity of raphia in relation to ammonia.

Table 5 Equations and parameters of the sorption equilibrium for individual sorbents

\begin{tabular}{|c|c|c|c|c|c|}
\hline Isotherm & Modification & Isotherm equation & $R^{2}$ & $\mathrm{Qmax}[\mathrm{mmol} / \mathrm{g}]$ & $K_{\mathrm{L}}[\mathrm{L} / \mathrm{mmol}]$ \\
\hline \multirow[t]{6}{*}{ Langmuir } & UM & $y=7.15 x+18.48$ & 0.9653 & 0.14 & 0.39 \\
\hline & $\mathrm{NaCl} 3 \mathrm{~h}$ & $y=6.67 x+12.57$ & 0.9510 & 0.15 & 0.53 \\
\hline & $\mathrm{NaCl} 54 \mathrm{~h}$ & $y=7.06 x+20.16$ & 0.8754 & 0.14 & 0.35 \\
\hline & NaNO3 $17 \mathrm{~h}$ & $y=8.76 x+13.76$ & 0.9870 & 0.11 & 0.64 \\
\hline & $\mathrm{K}_{2} \mathrm{SO}_{4} 16 \mathrm{~h}$ & $y=8.16 x+16.34$ & 0.9785 & 0.12 & 0.50 \\
\hline & Modification & Isotherm equation & $R^{2}$ & $\mathrm{~K}_{\mathrm{F}}\left(\mathrm{mg}^{-1(1 / \mathrm{n})}\left(\mathrm{dm}^{3}\right)^{1 / \mathrm{n}} \mathrm{g}^{-1}\right)$ & $1 / \mathrm{n}$ \\
\hline \multirow[t]{6}{*}{ Freudlich } & UM & $y=0.52 x-1.42$ & 0.9248 & 0.038 & 0.52 \\
\hline & $\mathrm{NaCl} 3 \mathrm{~h}$ & $y=0.43 x-1.28$ & 0.9355 & 0.053 & 0.43 \\
\hline & $\mathrm{NaCl} 54 \mathrm{~h}$ & $y=0.44 x-1.38$ & 0.9634 & 0.042 & 0.44 \\
\hline & $\mathrm{NaNO}_{3} 17 \mathrm{~h}$ & $y=0.41 x-1.36$ & 0.9788 & 0.044 & 0.41 \\
\hline & $\mathrm{K}_{2} \mathrm{SO}_{4} 16 \mathrm{~h}$ & $y=0.42 x-1.37$ & 0.9972 & 0.043 & 0.42 \\
\hline & Modification & Isotherm equation & $R^{2}$ & $\mathrm{~K}_{\mathrm{t}}\left[\mathrm{dm}^{3} / \mathrm{g}\right]$ & $\mathrm{B}$ \\
\hline \multirow[t]{6}{*}{ Temkin } & UM & $y=0.072 x+0.042$ & 0.9605 & 1.79 & 0.072 \\
\hline & $\mathrm{NaCl} 3 \mathrm{~h}$ & $y=0.073 x+0.056$ & 0.9207 & 2.15 & 0.073 \\
\hline & $\mathrm{NaCl} 54 \mathrm{~h}$ & $y=0.066 x+0.042$ & 0.8706 & 1.90 & 0.066 \\
\hline & $\mathrm{NaNO}_{3} 17 \mathrm{~h}$ & $y=0.057 x+0.046$ & 0.9737 & 2.25 & 0.057 \\
\hline & $\mathrm{K}_{2} \mathrm{SO}_{4} 16 \mathrm{~h}$ & $y=0.059 x+0.044$ & 0.9731 & 2.13 & 0.059 \\
\hline & Modification & Isotherm equation & $R^{2}$ & $\mathrm{E}(\mathrm{J} / \mathrm{mol})$ & $\mathrm{q}_{\mathrm{d}}(\mathrm{mmol} / \mathrm{g})$ \\
\hline \multirow[t]{5}{*}{ Dubinin-Radushkevich } & UM & $y=-0.044 x-1.46$ & 0.9575 & 3.38 & 0.23 \\
\hline & $\mathrm{NaCl} 3 \mathrm{~h}$ & $y=-0.035 x-1.50$ & 0.9499 & 3.79 & 0.22 \\
\hline & $\mathrm{NaCl} 54 \mathrm{~h}$ & $y=-0.035 x-1.70$ & 0.9383 & 3.77 & 0.18 \\
\hline & $\mathrm{NaNO}_{3} 17 \mathrm{~h}$ & $y=-0.033-1.77$ & 0.9892 & 3.91 & 0.17 \\
\hline & $\mathrm{K}_{2} \mathrm{SO}_{4} 16 \mathrm{~h}$ & $y=-0.33 x-1.76$ & 0.9897 & 3.87 & 0.17 \\
\hline
\end{tabular}



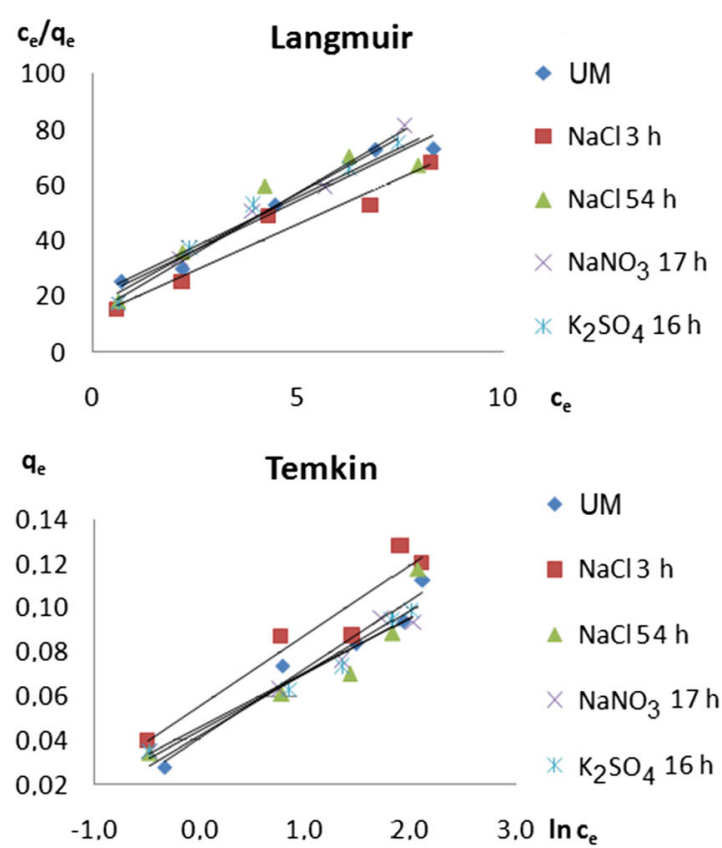

Fig. 6 Isotherms of ammonia sorption on raphia

\subsection{Equilibrium Studies}

In order to select a model of ammonia sorption equilibrium on raphia, the obtained data were analyzed in equilibrium. Isotherm equations and determined isothermal parameters for individual sorbents are presented in Table 5. In the case of raphia without surface modification and modified $\mathrm{NaCl}$ for $3 \mathrm{~h}$, the best fit to the measurement data was obtained for the Langmuir model (determination coefficient, respectively: $R^{2}=0.9653, R^{2}=$ 0.9510 ). The sorption equilibrium of raphia-modified surface for $54 \mathrm{~h}$ with $\mathrm{NaCl}$ and $\mathrm{K}_{2} \mathrm{SO}_{4}$ is best described by the Freundlich model $\left(R^{2}=0.9634\right.$ and $R^{2}=0.9972$, respectively) and raphia modified with the $\mathrm{NaNO}_{3}-\mathrm{D}-\mathrm{R}$ isotherm $\left(R^{2}=0.9892\right)$.

Based on the Langmuir equation, one can determine the $\mathrm{R}_{\mathrm{L}}$ constant $\left(R_{L}=\frac{1}{1+K_{F} C_{0}}\right)$, from which it can be concluded whether the conditions of the sorption process are favorable $\left(R_{\mathrm{L}}=0\right.$ : sorption is reversible, $0<R_{\mathrm{L}}$ $<1$ : sorption conditions are preferred, $R_{\mathrm{L}}=1$ : the nature of the sorption is linear, $R_{\mathrm{L}}>1$ : the sorption conditions are unfavorable) (Milonji et al. 2002).

For all initial ammonia concentrations, the $K_{\mathrm{L}}$ parameter ranges from 0 to 1 . On this basis, it can be assumed that sorption conditions of ammonia on raphia are favorable.

Figure 6 presents graphical representations of sorption equilibrium models for all types of sorbent. For individual cases, the measurement data deviate from the linearity: NaCl-modified raphia for $3 \mathrm{~h}$ and $\mathrm{NaCl}$ for $54 \mathrm{~h}$ in the Temkin model, raphia modified with $\mathrm{NaCl}$ for $54 \mathrm{~h}$ in the Langmuir model. In other cases, the $R^{2}$ determination coefficients are above 0.9249 . On this basis, it can be concluded that all four models of sorption equilibrium predict the equilibrium of sorption of ammonia on raphia in a reliable manner. This may be due to the concentration of ammonia in the modeled waste at the millimole level.

\subsection{Sorption Kinetics}

In order to confirm the sorption mechanism, an analysis of kinetics of ammonia sorption on raphia was performed. Four kinetic models of sorption were calculated: the pseudo-first-order model, the pseudo-second-order model, the Elovich model, and the intramolecular diffusion model. Table 6 presents sorption parameters of individual kinetic models for a given sorbent: unmodified raphia and four surface modification.

Compared with natural raphia fibers, the modified material showed higher ammonium adsorption 
Table 6 Kinetic parameters of different sorption models of ammonium

\begin{tabular}{|c|c|c|c|c|c|}
\hline \multirow{2}{*}{$\begin{array}{l}\text { Kinetic } \\
\text { model }\end{array}$} & \multicolumn{5}{|c|}{ Ammonium concentration $\mathrm{C}_{\mathrm{o}}\left(\mathrm{mmol} / \mathrm{dm}^{3}\right)$} \\
\hline & 1 & 3 & 5 & 7 & 9 \\
\hline
\end{tabular}

UM

Pseudo-first-order rate model

$\begin{array}{llllll}q \mathrm{e} & 0.0139 & 0.0414 & 0.0262 & 0.0211 & 0.0541 \\ \mathrm{k} 1 & 0.420 & 0.327 & 0.353 & 0.243 & 0.541 \\ R^{2} & 0.7971 & 0.9077 & 0.8661 & 0.7840 & 0.9381\end{array}$

Pseudo-second-order rate model

$\begin{array}{cccccc}q_{\mathrm{e}} & 0.030 & 0.079 & 0.087 & 0.096 & 0.116 \\ \mathrm{k} 2 & 35.43 & 12.17 & 32.63 & 35.31 & 25.91 \\ R^{2} & 0.9955 & 0.9964 & 0.9999 & 0.9997 & 0.9998\end{array}$

Elovich model

$\begin{array}{lccccc}\alpha & 0.07 & 0.20 & 4.42 & 33.88 & 34.57 \\ \beta & 162.07 & 65.99 & 97.06 & 112.38 & 92.14 \\ R^{2} & 0.8718 & 0.8716 & 0.8958 & 0.8720 & 0.9484\end{array}$

Intra-particle diffusion model

$\begin{array}{llllll}I & 0.0100 & 0.0267 & 0.0539 & 0.0659 & 0.0779 \\ K_{\text {id }} & 0.0059 & 0.0145 & 0.0099 & 0.0086 & 0.0107 \\ R^{2} & 0.6890 & 0.6996 & 0.7192 & 0.7111 & 0.8104\end{array}$

$\mathrm{NaCl} 3 \mathrm{~h}$

Pseudo-first-order rate model

$\begin{array}{llllll}q_{\mathrm{e}} & 0.0271 & 0.0428 & 0.0428 & 0.0374 & 0.0256 \\ \mathrm{k} 1 & 0.3756 & 0.2822 & 0.5358 & 0.6087 & 0.2355 \\ R^{2} & 0.9795 & 0.9394 & 0.9649 & 0.8942 & 0.6791\end{array}$

Pseudo-second-order rate model

$\begin{array}{llllll}q_{\mathrm{e}} & 0.0430 & 0.0911 & 0.0912 & 0.1307 & 0.1222 \\ \mathrm{k} 2 & 21.15 & 14.16 & 22.96 & 36.67 & 27.51\end{array}$

$\begin{array}{llllll}R^{2} & 0.9992 & 0.9996 & 0.9991 & 0.9999 & 0.9996\end{array}$

Elovich model

$\begin{array}{lccccc}\alpha & 0.09 & 0.48 & 0.81 & 291.30 & 16.20 \\ \beta & 118.90 & 67.43 & 70.23 & 96.87 & 77.92 \\ R^{2} & 0.9543 & 0.9349 & 0.8245 & 0.9049 & 0.7850\end{array}$

Intra-particle diffusion model

$\begin{array}{llllll}I & 0.0127 & 0.0385 & 0.0465 & 0.0970 & 0.0817 \\ K_{\text {id }} & 0.0083 & 0.0146 & 0.0133 & 0.00999 & 0.01197 \\ R^{2} & 0.8155 & 0.7945 & 0.6296 & 0.7438 & 0.5990\end{array}$

$\mathrm{NaCl} 54 \mathrm{~h}$

Pseudo-first-order rate model

$\begin{array}{llllll}q_{\mathrm{e}} & 0.0197 & 0.0429 & 0.0203 & 0.0277 & 0.0507 \\ \mathrm{k} 1 & 0.3304 & 0.5210 & 0.3377 & 0.3430 & 0.2278 \\ R^{2} & 0.9429 & 0.9851 & 0.7934 & 0.8074 & 0.9512\end{array}$

Pseudo-second-order rate model

$\begin{array}{lccccc}q_{\mathrm{e}} & 0.0365 & 0.0650 & 0.0719 & 0.0930 & 0.1218 \\ \mathrm{k} 2 & 30.57 & 19.77 & 36.02 & 24.83 & 11.40\end{array}$

Table 6 (continued)

\begin{tabular}{lccccc}
\hline $\begin{array}{l}\text { Kinetic } \\
\text { model }\end{array}$ & \multicolumn{5}{c}{ Ammonium concentration $\mathrm{C}_{\mathrm{o}}\left(\mathrm{mmol} / \mathrm{dm}^{3}\right)$} \\
\cline { 2 - 6 } & 1 & 3 & 5 & 7 & \multicolumn{2}{c}{9} \\
\hline$R^{2}$ & 0.9993 & 0.9989 & 0.9995 & 0.9990 & 0.9972 \\
Elovich model & & & & \\
$\alpha$ & 0.1315 & 0.2430 & 1.4628 & 1.4096 & 2.4320 \\
$\beta$ & 157.33 & 86.59 & 102.13 & 75.55 & 65.61 \\
$R^{2}$ & 0.9581 & 0.9357 & 0.7895 & 0.7502 & 0.9367 \\
Intra-particle diffusion model & & & \\
$I$ & 0.0135 & 0.0251 & 0.0415 & 0.0518 & 0.0626 \\
$K_{\text {id }}$ & 0.0063 & 0.0113 & 0.0091 & 0.0122 & 0.0156 \\
$R^{2}$ & 0.8332 & 0.7896 & 0.5947 & 0.5601 & 0.8594
\end{tabular}

$\mathrm{NaNO}_{3} 17 \mathrm{~h}$

Pseudo-first-order rate model

$\begin{array}{llllll}q_{\mathrm{e}} & 0.0239 & 0.0204 & 0.0235 & 0.0270 & 0.0332 \\ \mathrm{k} 1 & 0.3393 & 0.3438 & 0.3082 & 0.1553 & 0.2784 \\ R^{2} & 0.9686 & 0.6188 & 0.7970 & 0.5042 & 0.9857\end{array}$

Pseudo-second-order rate model

$\begin{array}{lccccc}q_{\mathrm{e}} & 0.0383 & 0.0658 & 0.0786 & 0.0967 & 0.0955 \\ \mathrm{k} 2 & 20.21 & 26.92 & 29.13 & 18.74 & 22.28 \\ R^{2} & 0.9986 & 0.9986 & 0.9995 & 0.9967 & 0.9993\end{array}$

Elovich model

\begin{tabular}{|c|c|c|c|c|c|}
\hline$\alpha$ & 0.0665 & 0.3894 & 1.1498 & 1.4930 & 10.5558 \\
\hline$\beta$ & 127.97 & 90.64 & 89.15 & 74.96 & 102.16 \\
\hline$R^{2}$ & 0.9528 & 0.8479 & 0.8156 & 0.7766 & 0.9722 \\
\hline \multicolumn{6}{|c|}{ Intra-particle diffusion model } \\
\hline$I$ & 0.0098 & 0.0305 & 0.0432 & 0.0523 & 0.0591 \\
\hline$K_{\mathrm{id}}$ & 0.0077 & 0.0104 & 0.0105 & 0.0126 & 0.0099 \\
\hline$R^{2}$ & 0.8092 & 0.6611 & 0.6237 & 0.6035 & 0.8799 \\
\hline
\end{tabular}

$\mathrm{K}_{2} \mathrm{SO}_{4} 16 \mathrm{~h}$

Pseudo-first-order rate model

$\begin{array}{llllll}q \mathrm{e} & 0.0234 & 0.0443 & 0.0352 & 0.0347 & 0.0337 \\ \mathrm{k} 1 & 0.266 & 0.661 & 0.365 & 0.231 & 0.217 \\ R^{2} & 0.9693 & 0.9497 & 0.9213 & 0.8238 & 0.7016\end{array}$

Pseudo-second-order rate model

$\begin{array}{cccccc}q_{\mathrm{e}} & 0.0381 & 0.0672 & 0.0777 & 0.0975 & 0.1011 \\ \mathrm{k} 2 & 17.64 & 18.56 & 17.73 & 16.93 & 17.66 \\ R^{2} & 0.9984 & 0.9970 & 0.9983 & 0.9991 & 0.9985\end{array}$

Elovich model

\begin{tabular}{|c|c|c|c|c|c|}
\hline$\alpha$ & 0.0628 & 0.1882 & 0.3228 & 0.9709 & 2.1231 \\
\hline$\beta$ & 131.96 & 76.64 & 72.66 & 69.53 & 76.79 \\
\hline$R^{2}$ & 0.9679 & 0.8887 & 0.8591 & 0.8554 & 0.9334 \\
\hline \multicolumn{6}{|c|}{ Intra-particle diffusion model } \\
\hline$I$ & 0.0091 & 0.0241 & 0.0324 & 0.0487 & 0.0546 \\
\hline$K_{\mathrm{id}}$ & 0.0076 & 0.0124 & 0.0130 & 0.0138 & 0.0129 \\
\hline$R^{2}$ & 0.8462 & 0.7091 & 0.6743 & 0.6873 & 0.8076 \\
\hline
\end{tabular}



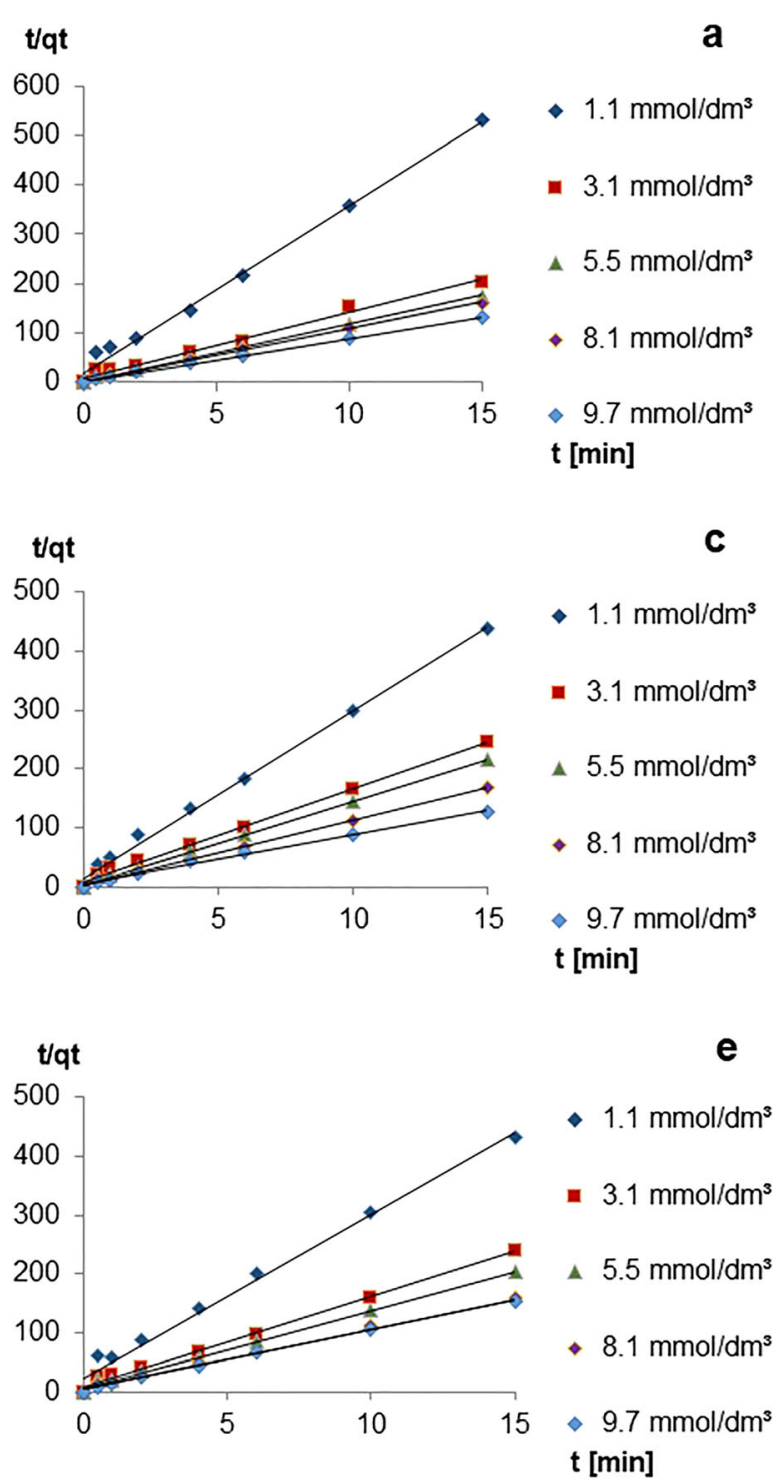

t/qt

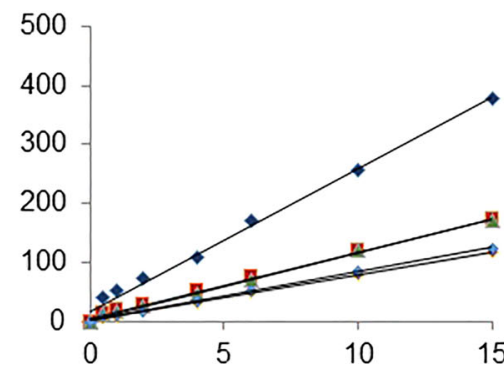

- $1.1 \mathrm{mmol} / \mathrm{dm}^{3}$

- $3.1 \mathrm{mmol} / \mathrm{dm}^{3}$

4. $5.5 \mathrm{mmol} / \mathrm{dm}^{3}$

$\downarrow 8.1 \mathrm{mmol} / \mathrm{dm}^{3}$

ه $9.7 \mathrm{mmol} / \mathrm{dm}^{3}$ $\mathbf{t}$ [min]

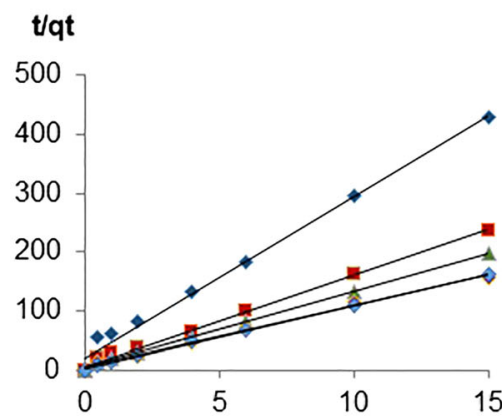

- $1.1 \mathrm{mmol} / \mathrm{dm}^{3}$

- $3.1 \mathrm{mmol} / \mathrm{dm}^{3}$

A $5.5 \mathrm{mmol} / \mathrm{dm}^{3}$

$48.1 \mathrm{mmol} / \mathrm{dm}^{3}$

$\diamond 9.7 \mathrm{mmol} / \mathrm{dm}^{3}$ t [min]

Fig. 7 Line graphs of pseudo-second order model of sorption kinetics for ammonium: a UM, b $\mathrm{NaCl} 3 \mathrm{~h}, \mathbf{c} \mathrm{NaCl} 54$ h, d NaNO $\mathrm{NaN}_{3} 17 \mathrm{~h}, \mathbf{e}$ $\mathrm{K}_{2} \mathrm{SO}_{4} 16 \mathrm{~h}$

capacity. For the lowest ammonium concentration, an increase in sorption capacity was observed for all modifications. The highest increase in sorption capacity was observed for 3-h modification with $\mathrm{NaCl}$, which was equal to $28 \%$. For other modifications, it was average $18-19 \%$. At concentrations of 3 and $5 \mathrm{mmol} / \mathrm{dm}^{3}$, an increase in sorption capacity was observed only on material modified with $\mathrm{NaCl}$ for $3 \mathrm{~h}(\sim 15 \%$ and $\sim 2.5 \%)$. For the remaining modifications, the sorption capacity was reduced by $17-$ $19 \%$ for $3 \mathrm{mmol} / \mathrm{dm}^{3}$ and $12-22 \%$ for $5 \mathrm{mmol} / \mathrm{dm}^{3}$, respectively. At a concentration of $7 \mathrm{mmol} / \mathrm{dm}^{3}$, an increase in sorption capacity was observed for three modifications by $\sim 27 \%(\mathrm{NaCl} 3 \mathrm{~h}), \sim 1.5 \%$ $\left(\mathrm{NaNO}_{3}\right)$, and $\sim 0.5 \%\left(\mathrm{~K}_{2} \mathrm{SO}_{4}\right)$. However, for a concentration of $9 \mathrm{mmol} / \mathrm{dm}^{3}$, an increase in sorption capacity was observed for $\mathrm{NaCl}$ modification, $6.5 \%$ for $3 \mathrm{~h}$ and $\sim 4.5 \%$ for $24 \mathrm{~h}$. Material modified with $\mathrm{NaNO}_{3}$ and $\mathrm{K}_{2} \mathrm{SO}_{4}$ decreased in its sorption capacity by $\sim 21 \%$ and $14.5 \%$. During the study, it was observed that the rate of reaching equilibrium between the bed and ammonium ions changed. For unmodified material, equilibrium was reached after $4 \mathrm{~min}$ for concentration equal to 1 and $3 \mathrm{mmol} / \mathrm{dm}^{3}$, 
and for 5-9 mmol/ $\mathrm{dm}^{3}$ after $6 \mathrm{~min}$. In the case of $\mathrm{NaCl}$ modification for $3 \mathrm{~h}$, equilibrium time was reached after $4 \mathrm{~min}$ for all tested concentrations. Other modifications resulted in equilibrium being reached after $6 \mathrm{~min}$ at all concentrations tested.

The most faithful mathematical description of the sorption kinetics of ammonia on raphia provides a pseudo-second-order model. The $R^{2}$ determination coefficient for all sorbent types and the entire range of concentrations tested is at least 0.9955 for this model. On this basis, it can be assumed that sorption of ammonia on raphia is of chemical nature (Ho 2006).

Figure 7 presents graphical interpretations of the sorption kinetics model for particular types of sorbent. One can notice a high adjustment of the measurement data to the pseudo-second-order model.

\section{Conclusion}

The research confirms that raphia sp. fibers can be used as a biosorbent to remove ammonia from water. The sorption capacity of raphia in relation to ammonia ranges from $0.093 \mathrm{mmol} / \mathrm{g}$ for $\mathrm{NaNO}_{3}$-modified raphia to $0.121 \mathrm{mmol} / \mathrm{g}$ for NaCl-modified raphia for $3 \mathrm{~h}$. The ammonia removal rate for unmodified raphia for concentrations of 5,7 , and $9 \mathrm{mmol} / \mathrm{dm}^{3}$ is equal to 24,17 , and $17 \%$, while for concentrations of 1 and $3 \mathrm{mmol} / \mathrm{dm}^{3}$ equal to $42 \%$ and $51 \%$, respectively. The highest increase in the removal of ammonia from the model solution relative to raphia with unmodified surface was observed for modification of the raphia surface using $\mathrm{NaCl}$ for $3 \mathrm{~h}$. At the lowest initial concentration, $1 \mathrm{mmol} / \mathrm{dm}^{3}$, the degree of ammonia removal increased by $60 \%$, while for the highest initial concentration, $9 \mathrm{mmol} / \mathrm{dm}^{3}$, increased by $8 \%$. The Freundlich sorption equilibrium model best describes the sorption of ammonia on all types of sorbent used ( $R^{2}$ equal to at least 0.9248 ), but the other models (Langmuir, Temkin, D-R) also correspond to the experimental data to a satisfactory degree $\left(R^{2}\right.$ equal to at least 0.8706 ). The kinetics of ammonia sorption from the model sewage on unmodified raphia and all types of surface modification is best described by the pseudosecond-order sorption kinetics model $\left(R^{2}\right.$ coefficient is at least equal to 0.9964$)$. On this basis, it can be concluded that the adsorption is of chemical nature.
Open Access This article is distributed under the terms of the Creative Commons Attribution 4.0 International License (http:// creativecommons.org/licenses/by/4.0/), which permits unrestricted use, distribution, and reproduction in any medium, provided you give appropriate credit to the original author(s) and the source, provide a link to the Creative Commons license, and indicate if changes were made.

\section{References}

Abdelnaeim, M. Y., El Sherif, I. Y., Attia, A. A., Fathy, N. A., \& El-Shahat, M. F. (2016). Impact of chemical activation on the adsorption performance of common reed towards cu(II) and cd(II). International Journal of Mineral Processing, 157, 8088.

Alberdi, O., Arriaga, H., Calvet, S., Estellés, F., \& Merino, P. (2016). Ammonia and greenhouse gas emissions from an enriched cage laying hen facility. Biosystems Engineering, 144, 1-12.

Appl, M. (1999). Ammonia, 1. Introduction. KGaA: Wiley-VCH Verlag $\mathrm{GmbH}$ and Co.

Araújo, C. S. T., Almeida, I. L. S., Rezende, H. C., Marcionilio, S. M. L. O., Léon, J. J. L., \& de Matos, T. N. (2018). Elucidation of mechanism involved in adsorption of $\mathrm{Pb}$ (II) onto Lobeira fruit (Solanum lycocarpum) using Langmuir, Freundlich and Temkin isotherms. Microchemical Journal, 137, 348-354.

Azimi, B., Tahmasebpoor, M., Sanchez-Jimenez, P. E., Perejon, A., \& Valverde, J. M. (2019). Multicycle CO2 capture activity and fluidizability of Al-based synthesized $\mathrm{CaO}$ sorbents. Chemical Engineering Journal, 358, 679-690.

Azizian, S., Eris, S., \& Wilson, L. D. (2018). Re-evaluation of the century-old Langmuir isotherm for modeling adsorption phenomena in solution. Chemical Physics, 513, 99-104.

Bhardwaj, N., \& Bhaskarwar, A. N. (2018). A review on sorbent devices for oil-spill control. Environmental Pollution, 243, 1758-1771.

Bispo, M. D., Schneider, J. K., Silva Oliveira, D., Tomasini, D., Silva Maciel, G. P., Schena, T., et al. (2018). Production of activated biochar from coconut fiber for the removal of organic compounds from phenolic. Journal of Environmental Chemical Engineering, 6, 2743-2750.

Chwastowski, J., Staroń, P., Kołoczek, H., \& Banach, M. (2017). Adsorption of hexavalent chromium from aqueous solutions using Canadian peat and coconut fiber. Journal of Molecular Liquids, 248, 981-989.

Coles, C. A., \& Yong, R. N. (2002). Aspects of kaolinite characterization and retention of $\mathrm{Pb}$ and $\mathrm{cd}$. Applied Clay Science, 22, 39-45.

Conley, D. J., Paerl, H. W., Howarth, R. W., Boesch, D. F., Seitzinger, S. P., Havens, K. E., Lancelot, C., \& Likens, G. E. (2009). ECOLOGY controlling eutrophication: Nitrogen and phosphorus. Science, 323, 1014-1015.

Cui, X., Hao, H., Zhang, C., He, Z., \& Yang, X. (2016). Capacity and mechanisms of ammonium and cadmium sorption on different wetland-plant derived biochars. Science of the Total Environment, 539, 566-575. 
Długosz, O., \& Banach, M. (2018a). Kinetic, isotherm and thermodynamic investigations of the adsorption of $\mathrm{Ag}+$ and $\mathrm{Cu} 2+$ on vermiculite. Journal of Molecular Liquids, 258, 295-309.

Długosz, O., \& Banach, M. (2018b). Sorption of Ag+ and Cu2+ by vermiculite in a fixed-bed column: Design, process optimization and dynamics investigations. Applied Sciences, 8, 2221.

Guo, X., \& Wang, J. (2019). A general kinetic model for adsorption: Theoretical analysis and modeling. Journal of Molecular Liquids, 288, 111100.

Henry, J., \& Aherne, J. (2014). Nitrogen deposition and exceedance of critical loads for nutrient nitrogen in Irish grasslands. Science of the Total Environment, 470-471, 216-223.

Ho, Y. S. (2006). Review of second-order models for adsorption systems. Journal of Hazardous Materials, B136, 681-689.

Hu, Y., Liu, W., Yang, Y., Qu, M., \& Li, H. (2019). $C_{2}$ capture by $\mathrm{Li}_{4} \mathrm{SiO}_{4}$ sorbents and their applications: Current developments and new trends. Chemical Engineering Journal, 359, 604-625.

Huang, J., Chen, J., Xie, Z., \& Xu, X. (2015). Treatment of nanofiltration concentrates of mature landfill leachate by a coupled process of coagulation and internal microelectrolysis adding hydrogen peroxide. Environmental Technology, 36, 1001-1007.

Hunt, A. M. W., \& Speakman, R. J. (2015). Portable XRF analysis of archaeological sediments and ceramics. Journal of Archaeological Science, 53, 626-638.

Inyang, H. I., Onwawoma, A., \& Bae, S. (2016). The Elovich equation as a predictor of lead and cadmium sorption rates on contaminant barrier minerals. Soil and Tillage Research, 155, 124-132.

Jorgensen, T. C., \& Weatherley, L. R. (2003). Ammonia removal from wastewater by ion exchange in the presence of organic contaminants. Water Research, 37, 1723-1728.

Lin, L., Lei, Z., Wang, L., Liu, X., Zhang, Y., Wan, C., Lee, D.-J., \& Tay, J. H. (2013). Adsorption mechanisms of high-levels of ammonium onto natural and $\mathrm{NaCl}$-modified zeolites. Separation and Purification Technology, 103, 15-20.

Milonji, S., Bispo, I., Fedoroff, M., Loos-Neskovic, C., \& VidalMadjar, C. (2002). Sorption of cesium on copper hexacyanoferrate/polymer/silica composites in batch and dynamic conditions. Journal of Radioanalytical and Nuclear Chemistry, 252, 497-501.
Petit, S., Righi, D., \& Madejová, J. (2006). Infrared spectroscopy of $\mathrm{NH}_{4}{ }^{+}$-bearing and saturated clay minerals: A review of the study of layer charge. Applied Clay Science, 34, 22-30.

Shalini, S. S., \& Joseph, K. (2012). Nitrogen management in landfill leachate: Application of Sharon, Anammox and combined Sharon-Anammox process. Waste Management, 32, 2385-2400.

Šiljeg, M., Foglar, L., \& Kukučka, M. (2010). The ground water ammonium sorption onto Croatian and Serbian clinoptilolite. Journal of Hazardous Materials, 178, 572-577.

Simonin, J. P. (2016). On the comparison of pseudo-first order and pseudo-second order rate laws in the modeling of adsorption kinetics. Chemical Engineering Journal, 300, 254-263.

Staroń, P., Chwastowski, J., \& Banach, M. (2017). Sorption and desorption studies on silver ions from aqueous solution by coconut fiber. Journal of Cleaner Production, 149, 290-301.

Veliscek-Carolan, J., Thorogood, G. J., Gregg, D. J., Tansu, M., \& Hanley, T. L. (2019). Ceramic conversion and densification of zirconium phosphonate sorbent materials. Journal of Nuclear Materials, 516, 327-334.

Veneu, D. M., Yokoyama, L., Cunha, O. G. C., Schneider, C. L., \& de Mello Monte, M. B. (2018). Nickel sorption using Bioclastic granules as a sorbent material: Equilibrium, kinetic and characterization studies. Journal of Materials Research and Technology, 209, 684-697.

Xu, Y., Ding, H., Luo, C., Zheng, Y., Xu, Y., Li, X., Zhang, Z., Shen, C., \& Zhang, L. (2018). Effect of lignin, cellulose and hemicellulose on calcium looping behavior of $\mathrm{CaO}$-based sorbents derived from extrusion-spherization method. Chemical Engineering Journal, 334, 2520-2529.

Zhang, T., Ding, L., \& Ren, H. (2009). Pretreatment of ammonium removal from landfill leachate by chemical precipitation. Journal of Hazardous Materials, 166, 911-915.

Zhu, Q., Moggridge, G. D., \& D’Agostino, C. (2016). Adsorption of pyridine from aqueous solutions by polymeric adsorbents MN 200 and MN 500. Part 2: Kinetics and diffusion analysis. Chemical Engineering Journal, 306, 1223-1233.

Publisher's Note Springer Nature remains neutral with regard to jurisdictional claims in published maps and institutional affiliations. 